wiązywania prawa azylu w obszarze wschodnim Morza Śródziemnego, gdzie najczęściej w dokumentach jest wymieniana Hagia Sophia. W obszarze zachodnim natomiast były to kościoły Rzymu, przede wszystkim bazyliki św. Piotra i św. Pawła. We wnioskach zaś stwierdza, że również teren obok budynków sakralnych był miejscem obowiązywania prawa azylu (s. 516).

Książkę kończy całościowe podsumowanie wyników badań (ss. 517-526). Dodatek (ss. 527-584) zawiera spis miejsc występowania w książce nazwisk autorów dzieł. Dolączone zostały również ilustracje ukazujące rozmieszczenie budynków w sanktuariach, którym przyznano przywilej prawa azylu, jak też rysunki przedstawiające fora rzymskie oraz kościoły greckie i rzymskie.

Autor postawił sobie za zadanie ukazać dla duchowego horyzontu azylu kościelnego solidny fundament źródłowy. Należy stwierdzić, ze uczynił to $z$ niezwykłą dokładnością. Żmudne odnotowywanie w przypisach materiałów źródłowych sprawia, że czytelnik ma bezpośredni wgląd w źródła. Zestawienie wielu opinii badaczy starożytności i wczesnego średniowiecza dotyczących prawa azylu i próba dyskusji z nimi pozwala na stwierdzenie, że Autor poprzez swoją książkę przyczynil się do wnikliwego spojrzenia na zjawisko azylu kościelnego. Wątpliwości może tylko budzić bardzo schematyczna budowa materiału zgromadzonego w trzech rozdziałach o takiej samej niemalże strukturze, co zmusilo Autora do powtórzeń. Książka może dostarczyć badaczom zajmującym się starożytnością i wczesnym średniowieczem wielu cennych materiałów dotyczących zjawiska azylu kościelnego.

ks. Krzysztof Burczak - Lublin, KUL

\title{
Ks. Antoni TRONINA - ks. Mariusz SZMAJDZIŃSKI, Wprowadzenie do języka syryjskiego, Kielce 2003, Wydawnictwo Instytutu Teologii Biblijnej „Verbum", ss. 160.
}

Z wielką radością należy powitać podręcznik do języka syryjskiego przygotowany przez ks. prof. A. Troninę (KUL) i jego doktoranta ks. mgr lic. M. Szmajdzińskiego, ponieważ jest to pierwszy podręcznik do tego języka na naszym rynku wydawniczym, nie licząc skrótowego zarysu gramatyki ks. P. Nowickiego sprzed 42 lat (Język syryjski. Zagadnienia podstawowe, Warszawa 1962), na 50 stronach. Wprowadzenie do języka syryjskiego ukazało się w niedawno powstałym Wydawnictwie Instytutu Teologii Biblijnej w Kielcach. Dzięki niemu ukazuje się półrocznik biblijno-teologiczny „Verbum Vitae” oraz książki w serii „Studia Biblica", w której szóstym tomem jest prezentowany podręcznik.

Język syryjski należy do mało znanych języków orientalnych. Należy on do aramejskiej rodziny języków semickich. $O$ jego przydatności wiedzą dobrze bibliści, patrologowie i historycy. To właśnie w tym języku powstała Peszitta 
(syryjskie tłumaczenie Biblii z ok. II wieku po Chr.), dzieła wielkich Ojców Kościoła, z Afrahatem i św. Efremem na czele oraz literatura apokryficzna, liturgiczna, a także kronikarska obszaru nestoriańskiego. Są to cenne skarby, które dobrze jest sobie przybliżyć nie tylko poprzez tłumaczenia na współczesne języki.

Wprowadzenie do jezyka syryjskiego "jest owocem wieloletniej praktyki dydaktycznej", jak zaznacza we wstępie autor ks. prof. A. Tronina, który od wielu już lat wykłada ten język w Instytucie Nauk Biblijnych KUL (na zmianę $\mathrm{z}$ językiem ugaryckim). Jest on znanym filologiem, egzegetą, biblistą i teologiem. Dzięki swej znajomości wielu języków starożytnych (nie tylko semickich), przetłumaczył na język polski już dużą ilość tekstów biblijnych (np. Księga Psalmów) i apokryficznych (np. Pokuta Adama). Ks. M. Szmajdziński natomiast próbuje podążyć jego filologicznymi śladami.

Podręcznik do języka syryjskiego został pod względem metodologicznym przygotowany bardzo poprawnie. Składa się on z czterech części (nie ma wyraźnego na nie podziału, ale zawarta treść na takowy pozwala). Pierwszą z nich stanowi czternaście jednostek lekcyjnych (ss. 11-78), w których zostały przedstawione podstawy gramatyki syryjskiej, głównie fleksja, choć nie brak też zagadnień ze składni. Każda $\mathrm{z}$ tych jednostek ma bardzo podobną budowę: rozpoczyna się kilkoma, najczęściej pięcioma, zdaniami oryginalnymi wraz $\mathrm{z}$ polskim tłumaczeniem. Są to $\mathrm{w}$ dużej mierze teksty biblijne, ale nie brak także cytatów ze starożytnych kronik i żywotów (np. Efrema Syryjczyka). Zdania zostały tak dobrane, aby ukazywały material gramatyczny zaznaczony w tytule jednostki lekcyjnej. Następnie przedstawiona jest szczególowa analiza tych poszczególnych zdań - podane nowe słówka, objaśnione ich formy i zależności między nimi, a także częściej spotykane wyjątki. Całość tych informacji jest zebrana w dalszej części jednostki, czyli w syntezie gramatyki, która odpowiada jej tytułowi. Bardzo często omawiany materiał jest przedstawiony w tabelach, co ułatwia uczenie się. Każda „lekcja” kończy się „pracą domową", tzn. ćwiczeniami, które polegają na przetłumaczeniu polskich zdań na język syryjski i odwrotnie, a przez to sprawdzają gruntownie przyswojone wiadomości; do ćwiczeń jest dołączony słowniczek.

Część kolejną podręcznika stanowią teksty do thumaczenia (ss. 79-113), których w sumie jest dziewięć. Ich wyboru dokonał ks. M. Szmajdziński i należy mu za to pogratulować! Tekstów nie ma dużo, co wiąże się $\mathrm{z}$ ramami podręcznika i programem nauczania, ale za to dają one szeroki ogląd literatury syryjskiej. Jak na biblistę przystało prezentację tekstów rozpocząl on od Pisma św., a dokładnie od prologu Ewangelii Janowej (J 1, 1-18). Inne teksty biblijne to: Ps 110 (tekst nr 2; jak wiadomo jest to jeden $\mathrm{z}$ trudniejszych tekstów do tłumaczenia $\mathrm{z}$ języka hebrajskiego i dlatego często sięga się do starożytnych przekładów, aby rozwiać wątpliwości), 1Sm 28, 4-25 (tekst nr 4: Saul u wróżki z Endor) i Mt 5, 1-16 (tekst nr 5: początek Kazania na Górze). W dalszej 
kolejności znajduje się perła wśród literatury syryjskiej, a mianowicie fragment z Listu króla Abgara z Edessy do Jezusa (tekst nr 3). Następnie zostały zamieszczone fragmenty reprezentatywnych tekstów Ojców Kościoła i innych pisarzy syryjskich w porządku chronologicznym: Arfahat - O Zmartwychwstaniu, Efrem - Pochwała biskupa Nisibis Abrahama, Jakub z Sarug - Prośby na dzień Sqdu Ostatecznego i Jozue Stylita - Kronika (o ile mi wiadomo ks. M. Szmajdziński ma zamiar przetłumaczyć i wydać całe to dzieło, które jest cennym świadectwem wojen persko-rzymskich z początku VI wieku, a także przygotowuje thumaczenie Ód Salomona). Wybór tych tekstów pozwala nie tylko na sprawdzenie swoich umiejętności w thumaczeniu, ale także pokazuje również piękno i bogactwo literatury syryjskiej, a także mentalność i wrażliwość jej autorów. Pierwsze trzy teksty są zaopatrzone w preparacje, które też uczą, jak analizować tekst.

Trzecia część Wprowadzenie do języka syryjskiego to słownik syryjskopolski (ss. 115-139), który jest stosunkowo bardzo obszerny. Jego wielką zaletą jest to, że obok polskiego znaczenia danego slowa zostały podane także odpowiedniki aramejskie, hebrajskie, greckie i łacińskie: to zaś ukazuje żywotność i ewolucję języka syryjskiego, a także jego zapożyczenia z innych języków.

Ostatnią część książki stanowią paradygmaty, w których zostały podane wzory odmian czasowników (s. 140-157). Ponadto, na całość prezentowanej książki składa się jeszcze bibliografia (s. 7-8), która jest podzielona na podręczniki, gramatyki i słowniki oraz wprowadzenie (s. 9-10). Bibliografia ta jest szczególnie pomocna dla tych, którzy chcieliby kontynuować naukę tego języka już we własnym zakresie. Jak widać, nie ma za dużo opracowań na ten temat. Dominuje język angielski, mniej niemiecki, są też starsze pozycje napisane jeszcze po łacinie. Tym bardziej należy się cieszyć, że mamy taką publikację w rodzimym języku polskim.

Wprowadzenie do języka syryjskiego jest podręcznikiem akademickim dla biblistów, patrologów i historyków, choć może służyć także jako pomoc do samodzielnej nauki. Dobrze by było, gdyby wówczas został dołączony tzw. klucz do ćwiczeń, w którym podane byłby thumaczenia zdań. Ktoś uczący się samodzielnie mógłby dzięki temu sprawdzić własne odpowiedzi. Można byłoby także uzupełnić pozostałe teksty preparacjami. Intencją autorów było zapewne, aby bardziej zachęcić do własnej pracy i dlatego podali je do trzech tylko pierwszych tekstów, które nie są wcale najtrudniejsze z tam zamieszczonych. Dzięki temu podręcznik miałby bez wątpienia szersze grono odbiorców. Do paradygmatów natomiast można jeszcze dołączyć tabelę z zaimkami dzierżawczymi.

W serii Studia Biblica ukazały się już dwie pomoce językowe. Oprócz tu omówionej są jeszcze Elementy składniowe biblijnego języka greckiego (tom 2). O ile mi wiadomo ks. prof. A. Tronina wraz z ks. M. Szmajdzińskim zamierzaja ją kontynuować i przygotować także podręcznik do języka ugaryckiego i ara- 
mejskiego. Jest to wspaniałe zamierzenie, które wychodzi naprzeciw potrzebom wykładowców i studentów oraz zapełnia wielką pustkę w tej dziedzinie na naszym rynku wydawniczym. Pozostaje życzyć im wytrwałości w zamierzeniu i cierpliwości w pracy.

ks. Marek Raszewski - Włoclawek

\begin{abstract}
Ks. Leszek MATEJA, Oblicza mitosierdzia. Historyczne uwarunkowania rozwoju doktryny o miłosierdziu. Studium dziet Tertuliana $i$ św. Cypriana, Kraków 2003, ss. 300.
\end{abstract}

W ostatnich latach $\mathrm{w}$ związku $\mathrm{z}$ rozszerzającym się kultem Miłosierdzia Bożego i św. siostry Faustyny Kowalskiej pojawia się na rynku wydawniczym szereg publikacji poświęconych czy to samej postaci siostry Faustyny, czy to historii kultu Miłosierdzia. Większość z nich to niestety literatura bardziej popularnokatolicka niż pozycje naukowe. Czasami jednak wśród nawału literatury, nie zawsze najwyższych lotów, trafiają się i swoiste perelki. I tak można potraktować książkę ks. Leszka Matei Oblicza mitosierdzia. Historyczne uwarunkowania rozwoju doktryny o mitosierdziu. Studium dzieł Tertuliana $i$ świętego Cypriana, opublikowaną przez wydawnictwo WAM, będącą publikacją pracy doktorskiej bronionej na Papieskiej Akademii Teologicznej w Krakowie w roku 2002, której promotorem był ks. prof. dr hab. Edward Staniek, a recenzentami ks. prof. dr hab. Wincenty Myszor i ks. prof. dr hab. Tomasz Jelonek.

Książka ks. Leszka Matei jest nie tylko perłą wśród książeczek o miłosierdziu, ale także unikalną pozycją pośród prac naukowych dotyczących miłosierdzia oraz Tertuliana i Cypriana z Kartaginy. Nie istniał do tej pory systematyczny wykład dotyczący rozwoju doktryny miłosierdzia u tych dwóch autorów. Pojawiały się pozycje poruszające bądź to tylko zagadnienie miłosierdzia jako miłości miłosiernej, bądź tylko miłosierdzia jako przebaczenia. Większość z tych dzieł jest zresztą dość leciwa i nie odzwierciedla obecnego stanu wiedzy, jak np.: M. Sieniatycki, Pokuta kościelna według Ojców Zachodnich w pierwszych pięciu wiekach, PT 2 (1921) 33-39, 147-160, 213-236; H. Pétré, Misericordia. Histoire du mot et de l'idée du paganisme au christianisme, REL 12 (1934) 376-389; L. Żarnowiecki, Mitosierdzie niewiast w starożytnym Kościele, „Ruch Charytatywny” 13 (1934) 376-378; B. Poschmann, Paenitentia secunda. Die kirchliche Buße im ältesten Christentum bis Cyprian und Origenes. Eine dogmengeschichtliche Untersuchung, Bonn 1940; C.B. Daly, The Sacrament of Penance in Tertulian, ,The Irish Ecclesiastical Record" 69 (1947) 693-707, 815-821; 70 (1948) 731-746, 832-848; A. Młotek, Nawrócenie i pokuta w nauczaniu Ojców Kościoła, HD 43 (1974) 98-105; 